\title{
Inhibitory effect of Fucofuroeckol-A from Eisenia bicyclis on tyrosinase activity and melanin biosynthesis in murine melanoma B16F10 cells
}

Kil Bo Shim *iD and Na Young Yoon

\begin{abstract}
Background: The aim of this study was to investigate the in vitro inhibitory effects of Fucofuroeckol-A isolated from Eisenia bicyclis against tyrosinase activity and 3-isobutyl-1-methylxanthine (IBMX)-induced melanin biosynthesis in B16F10 melanoma cells.

Result: Among the ethanolic (EtOH) extract of E. bicyclis and its organic solvent fractions, the ethyl acetate (EtOAc) soluble fraction showed a noticeable inhibitory effect on mushroom tyrosinase with an $I_{50}$ value of $37.6 \pm 0.1 \mu \mathrm{g} / \mathrm{mL}$. Repeated column chromatography of the active EtOAc fraction resulted in the isolation of Fucofuroeckol-A. It evidenced more potent tyrosinase inhibitory effect with an $I C_{50}$ value of $11.4 \pm 1.4 \mu \mathrm{M}$ than arbutin $\left(I C_{50}=1076.6 \pm 44.3 \mu \mathrm{M}\right)$, which was used as a positive control. Lineweaver-Burk plots suggest that Fucofuroeckol-A plays as a noncompetitive inhibitor against tyrosinase. Furthermore, we have evaluated the inhibitory effects of Fucofuroeckol-A on IBMX-induced melanin formation in B16F10 melanoma cells. Fucofuroeckol-A (12.5-100 $\mu \mathrm{M})$ exhibited a significant inhibition of melanin production in the melanoma cells.
\end{abstract}

Conclusion: In the present study, we suggested that Fucofuroeckol-A might prove possibility as a novel inhibitor of melanin biosynthesis in cosmetic applications.

Keywords: Eisenia bicyclis, Biosynthesis, Fucofuroekcol-A, Tyrosinase, B16F10 cell

\section{Background}

Melanin, a major pigment determines the color of skin, hair, and eyes, is synthesized within dermal melanocytes and plays a crucial role of protection against UV irradiation and oxidative stress-induced skin damage (Hanmura et al., 2008). Melanogenesis, melanin formation reaction, is initiated and modulated by tyrosinase (EC 1.14.18.1) in melanocytes confined in separate cytoplasmic organelles called melanosomes. Skin colors are determined by size, shape, amount, and distribution of occurred melanosomes (Lin and Fisher, 2007). Excessive generation and abnormal accumulation of melanin

\footnotetext{
* Correspondence: kilbo1221@korea.kr

Food Safety and Processing Research Division, National Institute of Fisheries Science, Busan 46083, Republic of Korea
}

pigments can lead to hyperpigmentation-related diseases, including melasma, freckles, nevus, ephelis, postinflammatory hyperpigmentation, senile lentigines, malignant melanomas, and aged spots (Picardo et al., 1999; Brenner and Hearing, 2008; Costin and Hearing, 2007). The inhibition of tyrosinase, a key enzyme of melanogenesis, is one of the most effective methods for suppressing increases in synthesis of the melanin pigment, and its inhibitors have been used to decrease pigmentation of food, skin, and pigmentary disorders in cosmetic, pharmaceutical, and food industry fields for a long time (Chen and Kubo, 2002; Lim et al., 2009; Nihei and Kubo, 2003; Matsuura et al., 2006; Seo et al., 2003; Tsuji-Naito et al., 2007). A variety of tyrosinase inhibitors such as glycolic acid, hydroquinone, kojic acid (Chang, 2009), ascorbic acid derivatives (Pillaiyar et al., 2017), azelaic acid (Hermanns et al., 2002), retinoids (Yoshimura et al., 2001), arbutin

(c) The Author(s). 2018 Open Access This article is distributed under the terms of the Creative Commons Attribution 4.0 International License (http://creativecommons.org/licenses/by/4.0/), which permits unrestricted use, distribution, and 
(Garcia-Jimenez et al., 2017), tretinoin, $N$-acetylglucosamine, niacinamide, linoleic acid, ellagic acid, methimazole, dioic acid, and rucinol (Seo et al., 2003) have been used to treat hyperpigmentation (Lee and Noh, 2013; Woolery-Lloyd and Kammer, 2011). However, hydroquinone and kojic acid, well known as skin-whitening agents, have undesirable side effects such as cytotoxicity, skin cancer, hepato-carcinogenesis, and dermatitis (Solano et al., 2006). Therefore, there is a need for safe and effective hypopigmentation agents from natural products, which are useful for the prevention of hyperpigmentation and pigmentation disorders and in the development of cosmetic resource as skin-whitening agents.

Eisenia bicyclis (Kjellman) Setchell is a perennial brown alga belonging to the family Laminariaceae that distributes throughout the coastal areas of Ullengdo and Dokdo in Republic of Korea. It has been used as a foodstuff, along with Laminaria japonica, Porphyra tenera, and Undaria pinnatifida. In previous researches, E. bicyclis has been studied its many beneficial bioactivities such as antioxidant, anti-dementia, anti-inflammation, and diabetic complication inhibitory effects (Fujii et al., 2013; Yoon et al., 2011; Jung et al., 2010; Shibata et al., 2007; Okada et al., 2004). In particular, phlorotannins, major metabolites of Eisenia, and Ecklonia species such as Eisenia bicyclis, Ecklonia stolonifera, and Ecklonia cava are polyphenolic compounds in algae and have been reported a variety of positive physiological effects including antioxidant, anti-dementia, anti-hyperlipidemic, angiotensin converting I enzyme, and quinone reductase inhibitory activities (Yoon et al., 2011; Yoon et al., 2008a; Yoon et al., 2008b; Jung et al., 2006; Yoon et al., 2013).

In the present study, we have investigated the inhibitory effects of Fucofuroeckol-A derived from $E$. bicyclis on mushroom tyrosinase activity and intracellular melanin formation in B16F10 murine melanoma cells. We also carried out kinetic analysis to evaluate the enzyme kinetic parameters and inhibition types.

\section{Materials and methods}

\section{Chemicals and reagents}

3-(4,5-Dimethyl-2-yl)-2,5-diphenyltetrazolium bromide (MTT), fetal bovine serum (FBS), Dulbecco's modified Eagle's medium (DMEM), arbutin, 3-isobutyl-1-methylxanthine (IBMX), dimethylsulfoxide (DMSO), phosphatebuffered saline (PBS), and mushroom tyrosinase (EC 1.14.18.1) were obtained from Sigma Chemical Company (St. Louis, MO). L-tyrosine and $\mathrm{K}_{2} \mathrm{HPO}_{4}$ were obtained from Junsei Chemical Co., Ltd. (Tokyo, Japan), and $\mathrm{KH}_{2} \mathrm{PO}_{4}$ was obtained from Yakuri Pure Chemicals Co., Ltd. (Osaka, Japan).

\section{Isolation of Fucofuroeckol-A from E. bicyclis}

Dried leafy thallus of E. bicyclis was purchased from Ullengdomall (Ullengdo, Republic of Korea) in September 2014 and was stored in a freezer at $-20{ }^{\circ} \mathrm{C}$ until use. A voucher specimen was deposited in the author's laboratory. The dried powder of E. bicyclis $(3.0 \mathrm{~kg}$ ) was extracted with ethanol $(\mathrm{EtOH}, 10 \mathrm{~L})$ three times at $70{ }^{\circ} \mathrm{C}$. The EtOH extract (624.3 g) was partitioned successively with organic solvents to yield dichloromethane $\left(\mathrm{CH}_{2} \mathrm{Cl}_{2}\right.$, $170.5 \mathrm{~g}$ ), ethyl acetate (EtOAc, $90.4 \mathrm{~g}$ ), and $n$-butanol ( $n-\mathrm{BuOH}, 100.8 \mathrm{~g}$ ) fractions, in addition to a $\mathrm{H}_{2} \mathrm{O}$ residue $(262.6 \mathrm{~g})$. The EtOAc fraction $(90.4 \mathrm{~g})$ of E. bicyclis was subjected to column chromatography over a Sephadex LH-20 with $\mathrm{MeOH}$, yielding 10 subfractions (EF01-EF10) based on TLC analysis. The RP-18 column chromatography of EF07 (1.6 g) using $40-60 \%$ aqueous $\mathrm{MeOH}$ led to the isolation of compound $1(32 \mathrm{mg})$. The structure of compound was identified as Fucofuroeckol-A and verified via a comparison to the published spectral data (Yoon et al., 2013).

\section{Tyrosinase inhibitory activity}

The inhibitory activity on tyrosinase was measured using the spectrophotometric method developed by No et al. (1999). A total of $10 \mu \mathrm{L}$ of each sample solution with different concentrations and $20 \mu \mathrm{L}$ of mushroom tyrosinase (1000 units $/ \mathrm{mL})$ in $50 \mathrm{mM}$ phosphate buffer $(\mathrm{pH}$ 6.5) were added to $170 \mu \mathrm{L}$ of an assay mixture containing a ratio of 10:10:9 of $1 \mathrm{mM}$ L-tyrosine solution, $50 \mathrm{mM}$ potassium phosphate buffer ( $\mathrm{pH}$ 6.5), and distilled water in a 96-well microplate. After $30 \mathrm{~min}$ of incubation at $37^{\circ}$ $\mathrm{C}$, the absorbance of the mixture was determined at $490 \mathrm{~nm}$ using spectrophotometer (BioMate 5; Thermo Electron, Waltham, MA, USA). The tyrosinase inhibitory activities of samples were expressed as the concentration required for a $50 \%$ inhibition $\left(\mathrm{IC}_{50}\right)$. The percentage inhibition of tyrosinase activity was calculated via the following equation:

$$
\text { Inhibitory activity }(\%)=[1-\{(A-B) / C\}] \times 100
$$

where, $A=$ absorbance at $490 \mathrm{~nm}$ with the test sample and enzyme, $B=$ absorbance at $490 \mathrm{~nm}$ with the test sample and without enzyme, and $C=$ absorbance at $490 \mathrm{~nm}$ with enzyme and without the test sample.

\section{Kinetic analysis}

The reaction mixture consisted of five different concentrations of L-tyrosine $(0.5-4 \mathrm{mM})$ as a substrate and mushroom tyrosinase in $50 \mathrm{mM}$ potassium phosphate buffer. Each sample was added to the reaction mixture at several different concentrations, respectively. The Michaelis constant $(\mathrm{Km})$ and maximal velocity $\left(V_{\max }\right)$ of the tyrosinase 
were determined by Lineweaver-Burk plots using various concentrations of L-tyrosine as substrates.

\section{Cell viability}

The murine melanoma B16F10 cells (KCLB no. 80008) were acquired from the Korean Cell Line Bank (KCLB, Seoul, Republic of Korea). B16F10 cells were maintained in DMEM supplemented with $10 \%$ heat-inactivated fetal bovine serum (FBS), 100 units $/ \mathrm{mL}$ penicillin $\mathrm{G}$, and $100 \mathrm{mg} / \mathrm{mL}$ streptomycin and cultured at $37{ }^{\circ} \mathrm{C}$ in a humidified atmosphere with $5 \% \mathrm{CO}_{2}$. The cytotoxicity levels of compounds on melanoma B16F10 cells were assessed via the MTT method as described by Mosmann (Hansen et al., 1989). The cells were grown in 96-well plates at a density of $1 \times 10^{4}$ cells/well. After $24 \mathrm{~h}$, the cells were washed in fresh medium and treated with different concentrations of samples. After $48 \mathrm{~h}$ of incubation, the cells were rewashed and $100 \mu \mathrm{L}$ of MTT solution $(5 \mathrm{mg} / \mathrm{ml})$ was added and incubated for $4 \mathrm{~h}$. Finally, DMSO $(100 \mu \mathrm{L})$ was added to solubilize the formed formazan salt, and the amount of formazan salt was quantified by measuring the absorbance at $540 \mathrm{~nm}$ using a spectrophotometer (BioMate 5; Thermo Electron, Waltham, MA, USA). Relative cell viability was determined by the quantity of MTT converted into formazan salt. Relative cell viability was calculated compared to the non-treated control group.

\section{Melanin contents analysis}

The melanin content of melanin formation in murine melanoma cell was determined in accordance with the procedure described by Hosoi et al. (1985). The B16F10 melanoma cells were seeded at a density of $2 \times 10^{4}$ cells per well in 24-well culture plates and then incubated for $24 \mathrm{~h}$. The cells were treated with various concentrations of sample (12.5-100 $\mu \mathrm{M})$. After $1 \mathrm{~h}, 100 \mu \mathrm{M}$ 3-isobutyl1-methylxanthine (IBMX) was added and incubated for $72 \mathrm{~h}$. The cells were washed twice in PBS and dissolved in $1 \mathrm{~N} \mathrm{NaOH}$ (in 10\% DMSO) by 30 min of boiling $\left(60{ }^{\circ} \mathrm{C}\right)$.

Table 1 Tyrosinase inhibitory activity of the methanolic extract of E. bicyclis and its solvent fractions

\begin{tabular}{ll}
\hline Samples & $\mathrm{IC}_{50}(\mathrm{\mu g} / \mathrm{mL})^{a}$ \\
\hline EtOH ex. & $499.0 \pm 6.6$ \\
n-hexane fr. & $>1000$ \\
$\mathrm{CH}_{2} \mathrm{Cl}_{2}$ fr. & $254.2 \pm 0.3$ \\
$\mathrm{EtOAC} \mathrm{fr.}$ & $37.6 \pm 0.1$ \\
$\mathrm{n}-\mathrm{BuOH}$ fr. & $82.4 \pm 0.1$ \\
$\mathrm{H}_{2} \mathrm{O}$ fr. & $514.9 \pm 9.4$ \\
Arbutin $^{b}$ & $299.3 \pm 12.3$ \\
\hline
\end{tabular}

Inhibition activity was expressed as $50 \%$ inhibitory concentration obtained by interpolation of the concentration inhibition \%

${ }^{b}$ Arbutin was used as a positive control

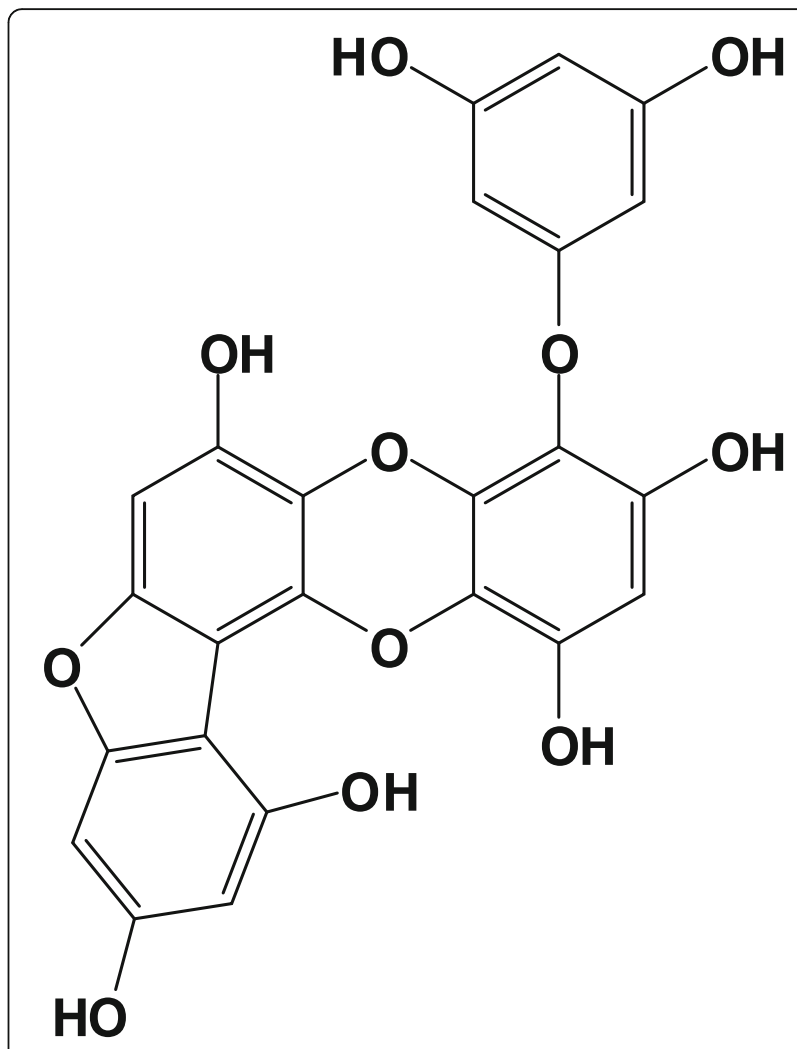

Fig. 1 Chemical structure of Fucofuroeckol-A

The lysates were centrifuged for $5 \mathrm{~min}$ at $\times 3000 \mathrm{~g}$, and then, the absorbance value of the supernatant was measured at $405 \mathrm{~nm}$.

\section{Statistical analysis}

Data were expressed as the mean \pm standard deviation (SD) values of three experiments. The means were statistically analyzed using Student's $t$ test. Values of $p<0.001$, 0.01 , and 0.05 were considered statistically significant.

\section{Results and discussion}

In this study, we attempted to estimate the tyrosinase inhibitory activities of the $\mathrm{EtOH}$ extract derived from $E$. bicyclis, along with its solvent soluble fractions, including n-hexane, $\mathrm{CH}_{2} \mathrm{Cl}_{2}$, EtOAc, $\mathrm{n}-\mathrm{BuOH}$, and a $\mathrm{H}_{2} \mathrm{O}$ layer and their data were shown in Table 1. Among the EtOH

Table 2 Tyrosinase inhibitory activity of Fucofuroeckol-A derived from active EtOAc fraction of E. bicyclis

\begin{tabular}{ll}
\hline Samples & $\mathrm{IC}_{50}(\mu \mathrm{M})^{a}$ \\
\hline Fucofureockol-A & $11.4 \pm 1.4$ \\
Arbutin $^{b}$ & $1076.6 \pm 44.3$ \\
\hline
\end{tabular}

Inhibition activity was expressed as 50\% inhibitory concentration obtained by interpolation of the concentration inhibition \%

${ }^{\mathrm{b}}$ Arbutin was used as a positive control 


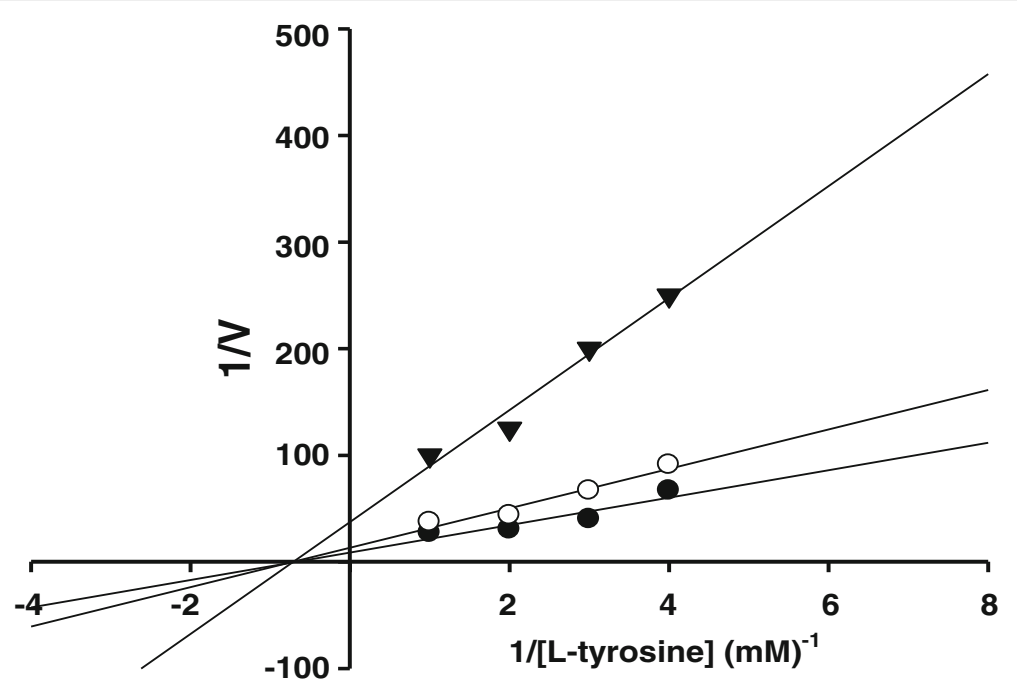

Fig. 2 Lineweaver-Burk plot of mushroom tyrosinase in the presence of Fucofuroeckol-A. Data were expressed as the means of three independent test concentration of L-tyrosine used as a substrate. Concentrations of Fucofuroeckol-A as an inhibitor were as follows: $\mathbf{\Delta}, 20 \mu \mathrm{M} ; 0,10 \mu \mathrm{M} ; \bullet$, control

extract of E. bicyclis and its partitioned fractions, the EtOAc-soluble fraction exhibited the most potent tyrosinase inhibition activity $\mathrm{IC}_{50}$ value of $37.6 \pm 0.1 \mu \mathrm{g} / \mathrm{mL}$. The EtOAc fraction exhibited more noticeable inhibitory activity on tyrosinase than that of arbutin $\left(\mathrm{IC}_{50}\right.$ value of $299.3 \pm 12.3 \mu \mathrm{g} / \mathrm{mL}$ ), which was employed as a positive control. According to the previous studies, the EtOAc fraction of E. bicyclis contains above $70 \%$ polyphenols and it is composed of phlorotannins, representative polyphenolic components of Eisenia sp. (Yoon et al., 2011; Yoon et al., 2013).

For further phytochemical investigations, we undertook the isolation of bioactive compounds from the active EtOAc fraction via repeated column chromatography over Sephadex LH-20 and RP-18 gel, which led to the isolation of one compound. The structure of compound was verified by spectroscopic analyses and identified by comparisons to published data (Elyashberg, 2015). The chemical structure of compound was identified as Fucofuroeckol-A (Fig. 1). The inhibitory effect of Fucofuroeckol-A against mushroom tyrosinase was also evaluated (Table 2). Fucofuroeckol-A showed potent inhibitory activity on tyrosinase with $\mathrm{IC}_{50}$ values of $11.4 \pm 1.4 \mu \mathrm{M}$. In particular, Fucofuroeckol-A evidenced inhibitory effects 94-fold stronger than that of the positive control, arbutin $(1076.6 \pm 44.3 \mu \mathrm{M})$.

The inhibition kinetic study of Fucofuroeckol-A on tyrosinase-induced L-tyrosine oxidation was determined by using a Lineweaver-Burk plot. The Lineweaver-Burk plots in the presence of Fucofuroeckol-A yield three straight lines with different slopes and with a common intercept on the $X$-axis. Its kinetic parameters of tyrosinase were shown in Fig. 2 and Table 3. The Ki values of Fucofuroeckol-A were estimated to be $1.3 \mu \mathrm{M}$ at $2.3 \mu \mathrm{M}$ and 6.4 $\mu \mathrm{M}$ at 7.4 $\mu \mathrm{M}$, respectively. The tyrosinase inhibitory activity of Fucofuroeckol-A exhibited the same Km value of $1.4 \times 10^{-3} \mathrm{M}$ and $V_{\max }$ values of $7.5 \times 10^{-2}$ and $2.7 \times 10^{-2} \Delta \mathrm{OD} 490 / \mathrm{min}$ at 1.3 and $6.4 \mu \mathrm{M}$, respectively. Therefore, these results indicated that FucofuroeckolA was identified as a noncompetitive inhibitor of the mushroom tyrosinase which can bind with both the free enzyme and the enzyme-substrate complex, and the equilibrium constants are the same.

To further verify the inhibitory property of Fucofuroeckol-A on melanogenesis, we examined the inhibitory effect of Fucofuroeckol-A on IBMX-induced melanin synthesis in murine melanoma (B16F10) cells. We first evaluated the cell viability of FucofuroeckolA and arbutin, used as a positive control, using MTT assay on B16F10 cells. These exerted no cytotoxicity on B16F10 cell in the concentration range of 12.5$100 \mu \mathrm{M}$ and $0.5-3.6 \mathrm{mM}$, respectively (data not shown). Thus, we investigated the inhibitory effects of Fucofuroeckol-A on IBMX-induced melanin synthesis in dose range without cytotoxicity. IBMX, a well-known melanogenesis stimulator, act as a potent cyclic adenosine monophosphate (cAMP) phosphodiesterase inhibitor and is increased cAMP in melanocytes (Röhrig et al., 2017; Levy et al., 2016). cAMP is regarded as a key messenger in the regulation of melanin synthesis. It has been shown to

Table 3 Kinetic parameters of tyrosinase in the presence of Fucofuroeckol-A

\begin{tabular}{llll}
\hline Compound & $\mathrm{Km}(\mathrm{M})$ & $V_{\max }\left(\Delta \mathrm{OD}_{490} / \mathrm{min}\right)$ & $\mathrm{Ki}(\mu \mathrm{M})$ \\
\hline Fucofureockol-A & $1.41 \times 10^{-3}$ & & \\
$1.28 \mu \mathrm{M}$ & & $7.51 \times 10^{-2}$ & 2.28 \\
$6.40 \mu \mathrm{M}$ & & $2.67 \times 10^{-2}$ & 7.40 \\
\hline
\end{tabular}




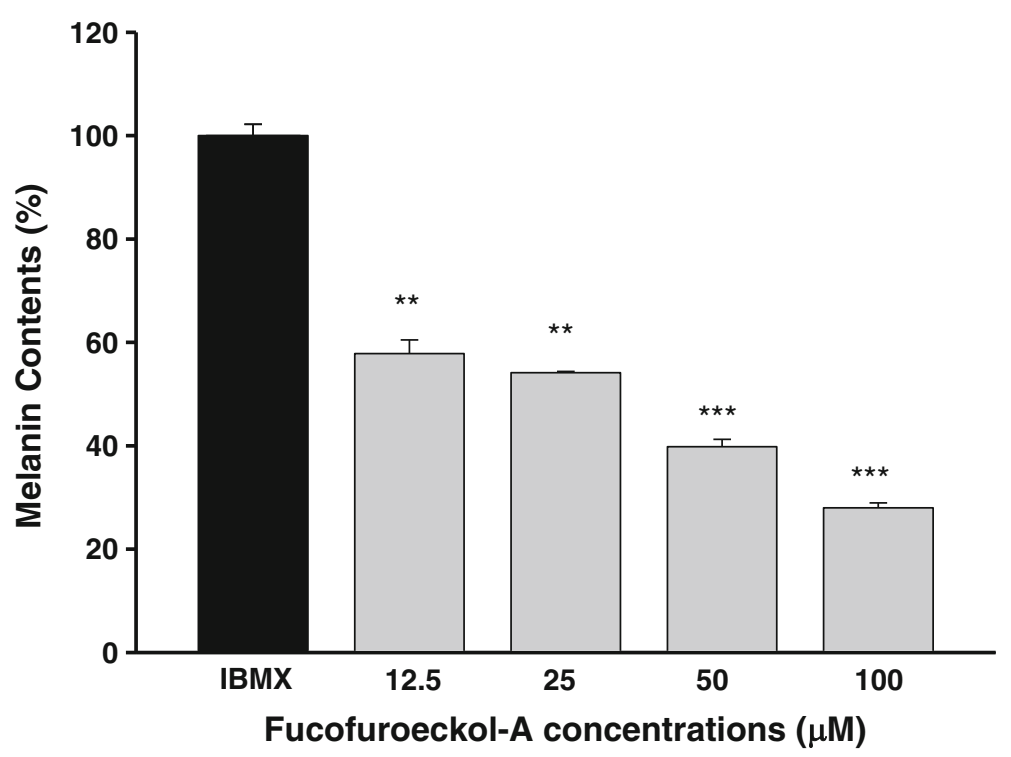

Fig. 3 Inhibitory effects of Fucofuroeckol-A on IBMX-induced melanin formation in B16F10 melanoma cells. The values are expressed as the means \pm SD from three experiments. $\left(^{*}\right) P<0.05,\left(^{* *}\right) P<0.01$, and $\left(^{* * *}\right) P<0.001$ versus the IBMX-treated group

induce significant elevations in melanin production following a single treatment in melanoma cells (Buscà and Ballotti, 2000). Fucofuroeckol-A exhibited significant inhibitory effects against melanin synthesis and reduced significantly its melanin content in a dose-dependent manner on IBMX-induced melanin synthesis in B16F10 cells (Fig. 3). However, arbutin, used as a positive control, showed a moderate melanin formation inhibitory effect and its melanin contents declined at the concentration range of $0.5-3.6 \mathrm{mM}$ on IBMX-induced melanin synthesis in B16F10 cells (Fig. 4). As shown in Table 4, Fucofuroeckol-A with $\mathrm{EC}_{50}$ value of $31.9 \pm 2.8 \mu \mathrm{M}$ was shown to function as a potent melanin production inhibitor on IBMX-induced melanin production in B16F10 melanoma cells and its efficacy was much better than that of arbutin $\left(E_{50}=4100 \pm 257 \mu \mathrm{M}\right)$.

In the present study, it was demonstrated that Fucofuroeckol-A exerted significant inhibitory effects on both mushroom tyrosinase and melanin synthesis in melanoma cells. According to previous researches, the

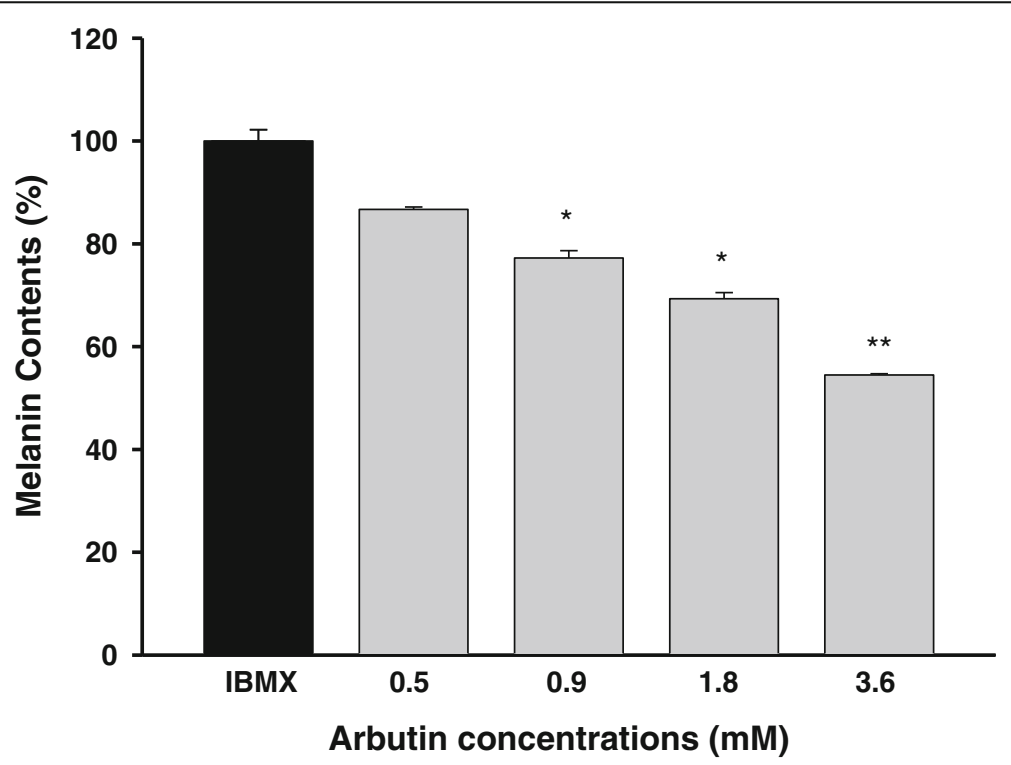

Fig. 4 Inhibitory effects of arbutin on IBMX-induced melanin formation in B16F10 melanoma cells. The values are expressed as the means \pm SD from three experiments. $\left(^{*}\right) P<0.05$ and $\left(^{* *}\right) P<0.01$ versus the IBMX-treated group 
Table 4 Inhibitory effects of Fucofuroeckol-A on IBMX-induced melanin formation in B16F10 melanoma cells

\begin{tabular}{ll}
\hline Samples & $\mathrm{EC}_{50}(\mu \mathrm{M})^{a}$ \\
\hline Fucofureockol-A $^{a}$ & $31.9 \pm 2.8$ \\
Arbutin $^{b}$ & $4100 \pm 257$ \\
\hline
\end{tabular}

${ }^{a}$ Data were expressed as $50 \%$ effective concentration

${ }^{\mathrm{b}}$ Arbutin was used as a positive control

inhibitory effects on the mushroom tyrosinase and melanin synthesis in melanoma cells of various phlorotannins such as phloroglucinol, dioxinodehydroeckol, eckol, phlorofucofuroeckol-A, dieckol, and 7-phlorockol derived from Ecklonia stolonifera and Ecklonia cava were reported (Kang et al., 2004; Yoon et al., 2009). However, this is the first report concerning the hypopigmentation effects of Fucofuroeckol-A derived from Eisenia bicyclis.

The various biological activities of Fucofuroeckol-A have been investigated, including pancreatic lipase, $\alpha$ glucosidase and $\alpha$-amylase inhibitory activities, antimicrobial and antibacterial effects, and quinone reductase induction activity (Eom et al., 2012a, b and 2013; Lee et al., 2015; Yoon et al., 2013).

Arbutin, used as a positive control, is a well-known tyrosinase inhibitor. However, despite its low efficacy, it has been commercially used as skin-whitening cosmetic ingredient and medicinal agent for the treatment of a variety of cutaneous hyperpigmentation disorders because of its safety (Solano et al., 2006).

In the present study, we have demonstrated that the ethanolic extract of E. bicyclis and its bioactive compound, Fucofuroeckol-A, exhibited potent inhibitory effects on mushroom tyrosinase. Fucofuroeckol-A was also identified as a noncompetitive inhibitor against mushroom tyrosinase and evidenced a significant inhibitory effect on IBMX-induced melanin synthesis in B16F10 melanoma cells.

Therefore, these results indicated the possibility of Fucofuroeckol-A from E. bicyclis can be a good candidate as a hyperpigmentation inhibitor or a skin-whitening agent in cosmetic industry. Furthermore, we plan to conduct additional studies into the mechanisms underlying the inhibitory properties of this compound.

\section{Conclusion}

In the present study, we were demonstrated that the ethanolic extract of E. bicyclis and its bioactive compound, Fucofuroeckol-A, exhibited potent inhibitory effects on mushroom tyrosinase. Fucofuroeckol-A was also identified as a noncompetitive inhibitor against mushroom tyrosinase and evidenced a significant inhibitory effect on IBMX-induced melanin synthesis in B16F10 melanoma cells.

\section{Abbreviations}

CAMP: Cyclic adenosine monophosphate; DMEM: Dulbecco's modified Eagle's medium; DMSO: Dimethylsulfoxide; EtOAc: Ethyl acetate; EtOH: Ethanol; FBS: Fetal bovine serum; IBMX: 3-Isobutyl-1-methylxanthine; KCLB: Korean Cell Line Bank; MTT: 3-(4, 5-Dimethyl-2-yl)-2,5-diphenyltetrazolium bromide; PBS: Phosphate-buffered saline

\section{Acknowledgements}

This study was supported by a grant from the National Institute of Fisheries Science (R2018061).

\section{Availability of data and materials}

Not applicable.

\section{Authors' contributions}

KB Shim and NA Yoon designed this study, carried out the analysis of the extraction and biological activities for skin whitening from Eisenia bicyclis, and drafted the manuscript. Both authors have read and approved the final version of the manuscript.

Ethics approval and consent to participate

Not applicable.

Consent for publication

Not applicable.

\section{Competing interests}

The authors declare that they have no competing interests.

\section{Publisher's Note}

Springer Nature remains neutral with regard to jurisdictional claims in published maps and institutional affiliations.

Received: 9 September 2018 Accepted: 4 November 2018

Published online: 28 November 2018

\section{References}

Brenner M, Hearing VJ. The protective role of melanin against UV damage in human skin. Photochem Photobiol. 2008;84:539-49.

Buscà R, Ballotti R. Cyclic AMP a key messenger in the regulation of skin pigmentation. Pigment Cell Melanoma Res. 2000;13:60-9.

Chang TS. An updated review of tyrosinase inhibitors. Int J Mol Sci. 2009;10: 2440-75.

Chen QX, Kubo I. Kinetics of mushroom tyrosinase inhibition by quercetin. J Agric Food Chem. 2002;50:4108-12.

Costin GE, Hearing VJ. Human skin pigmentation: melanocytes modulate skin color in response to stress. FASEB J. 2007;21:976-94.

Elyashberg M. Identification and structure elucidation by NMR spectroscopy. Trends Analyt Chem. 2015;69:88-97.

Eom SH, Kim YM, Kim SK. Antimicrobial effect of phlorotannins from marine brown algae. Food Chem Toxicol. 2012a;50:3251-5.

Eom SH, Lee MS, Lee EW, Kim YM, Kim TH. Pancreatic lipase inhibitory activity of phlorotannins isolated from Eisenia bicyclis. Phytother Res. 2013;27:148-51.

Eom SH, Lee SH, Yoon NY, Jung WK, Jeon YJ, Kim SK, Lee MS, Kim YM. aGlucosidase- and a-amylase inhibitory activities of phlorotannins from Eisenia bicyclis. J Sci Food Agric. 2012b;92:2084-90.

Fujii Y, Tanaka R, Miyake H, Tamaru Y, Ueda M, Shibata T. Evaluation for antioxidative properties of phlorotannins isolated from the brown alga Eisenia bicyclis, by the H-ORAC method. Food Nutr Sci. 2013:4:78-82.

Garcia-Jimenez A, Teruel-Puche JA, Berna J, Rodriguez-Lopez JN, Tudela J, GarciaCanovas F. Action of tyrosinase on alpha and beta-arbutin: A kinetic study. PLoS One. 2017;12:1-26.

Hanmura T, Uchida E, Aoki H. Skin-lightening effects of a polyphenol extract from Acerola (Malpighia emarginata DC.) fruit on UV-induced pigmentation. Biosci Biotechnol Biochem. 2008;72:3211-8.

Hansen MB, Nielsen SE, Berg K. Re-examination and further development of a precise and rapid dye method for measuring cell growth/cell kill. J Immunol Methods. 1989;119:203-10.

Hermanns JF, Petit L, Pierard-franchimont C, Paquet P, Pierard GE. Assessment of topical hypopigmentation agents on solar lentigines of Asian woman. Dermatology. 2002;204:281-6. 
Hosoi J, Abe E, Suda T, Kuroki T. Regulation of melanin synthesis of B16 mouse melanoma cells by 1a, 25-dihydroxyvitamin $\mathrm{D}_{3}$ and retinoic acid. Cancer Res. 1985;45:1474-8.

Jung HA, Hyun SK, Kim HR, Choi JS. Angiotensin convertin enzyme I inhibitory activity of phlorotannins from Ecklonia stolonifera. Fish Sci. 2006;72:1292-9.

Jung HA, Oh SH, Choi JS. Molecular docking studies of phlorotannins from Eisenia bicyclis with BACE1 inhibitory activity. Bioorg Med Chem Lett. 2010;20: 3211-5.

Kang HS, Kim HR, Byun DS, Son BW, Nam TJ, Choi JS. Tyrosinase inhibitors isolated from the edible brown alga Ecklonia stolonifera. Arch Pharm Res. 2004;27:1226-32.

Lee AY, Noh M. The regulation of epidermal melanogenesis via CAMP and/or PKC signaling pathways: insight for the development of hypopigmentating agents. Arch Pharm Res. 2013;36:792-801.

Lee JH, Eom SH, Lee EH, Jung YJ, Kim HJ, Jo MR, Son KT, Lee HJ, Kim JH, Lee MS, Kim YM. In vitro antibacterial and synergistic effect of phlorotannins isolated from edible brown seaweed Eisnia bicyclis against acne related bacteria. Algae. 2015;29:47-55

Levy J, Zhou DM, Zippin JH. Cyclic adenosine monophosphate signaling in inflammatory skin disease. J Clin Exp Dermatol Res. 2016;7:1-10.

Lim YJ, Lee EJ, Kang TH, Ha SK, Oh MS, Kim SM, Yoon TJ, Kang CH, Park JH, Kim SY. Inhibitory effects of arbutin on melanin biosynthesis of a-melanocyte stimulating hormone-induced hyperpigmentation in cultured brownish Guinea pig skin tissues. Arch Pharm Res. 2009;32:367-73.

Lin JY, Fisher DE. Melanocyte biology and skin pigmentation. Nature. 2007:445: $843-50$.

Matsuura R, Ukeda H, Sawamura M. Tyrosinase inhibitory activity of citrus essential oil. J Agric Food Chem. 2006:54:2309-13.

Nihei K, Kubo I. Identification of oxidation product of arbutin in mushroom tyrosinase assay system. Bioorg Med Chem Lett. 2003;13:2409-12.

No JK, Soung DY, Kim YJ, Shim KH, Jun YS, Rhee SH, Yokozawa T, Chung HY. Inhibition of tyrosinase by green tea components. Life Sci. 1999:65:241-6.

Okada Y, Ishimaru A, Suzuki R, Okuyama T. A new phloroglucinol derivative from the brown alga Eisenia bicyclis: potential for the effective treatment of diabetic complications. J Nat Prod. 2004;67:103-5.

Picardo M, Maresca V, Eibenschutz L, De Bernardo C, Rinaldi R, Grammatico P. Correlation between antioxidants and phototypes in melanocytes cultures. A possible link of physiologic and pathologic relevance. J Invest Dermatol. 1999; 113:424-5.

Pillaiyar T, Manickamb M, Namasivayama V. Skin whitening agents: medicinal chemistry perspective of tyrosinase inhibitors. J Enzyme Inhib Med Chem. 2017:32:403-25

Röhrig T, Pacjuk O, Hernández-Huguet S, Körner J, Scherer K, Richling E. Inhibition of cyclic adenosine monophosphate-specific phosphodiesterase by various food plant-derived phytotherapeutic agents. Medicines. 2017;4:80.

Seo SY, Sharma VK, Sharma N. Mushroom tyrosinase: recent prospects. J Agric Food Chem. 2003:51:2837-53.

Solano F, Briganti S, Picardo M, Ghanem G. Hypopigmenting agents: an updated review on biological, chemical, and clinical aspects. Pigment Cell Res. 2006; 19:550-71.

Shibata T, Ishimaru K, Kawaguchi S, Yoshikawa H, Hama Y. Antioxidant activities of phlorotannins isolated from Japanese Laminariaceae. Nineteenth International Seaweed Symposium. 2007;255-61.

Tsuji-Naito K, Hatani T, Okada T, Tehara T. Modulating effects of a novel skin lightening agent, alpha-lipoic acid derivative, on melanin production by the formation of DOPA conjugate products. Bioorg Med Chem. 2007;15:1967-75.

Woolery-Lloyd H, Kammer JN. Treatment of hyperpigmentation. Semin Cutan Med Surg. 2011;30:171-5

Yoon NY, Chung HY, Kim HR, Choi JS. Acetyl- and butyrylcholinesterase inhibitory activities of sterols and phlorotannins from Ecklonia stolonifera. Fish Sci. 2008a;74:200-7.

Yoon NY, Eom TK, Kim MM, Kim SK. Inhibitory effect of phlorotanins isolated from Ecklonia cava on mushroom tyrosinase activity and melanin formation in mouse B16F10 melanoma cells. J Agric Food Chem. 2009:57:4124-9.

Yoon NY, Kim HR, Chung HY, Choi JS. Anti-hyperlipidemic effect of an edible brown algae, Ecklonia stolonifera, and its constituents on poloxamer 407induced hyperlipidemic and cholesterol-fed rats. Arch Pharm Res. 2008b;31: 1564-71.

Yoon NY, Lee SH, Shim KB, Lim CW, Lee MH, Cho HA, Xie CL. Quinone reductase induction activity of phlorotannins derived from Eisenia bicyclis. Fish Aquat Sci. 2013;16:1-5.
Yoon NY, Lee SH, Wijesekara I, Kim SK. In vitro and intracellular antioxidant activities of brown alga Eisenia bicyclis. Fish Aquat Sci. 2011:14:179-85.

Yoshimura K, Tsukamoto K, Okazaki M, Virador VM, Lei TC, Suzuki Y, Uchida G, Kitano Y, Harii K. Effects of all-trans retinoic acid on melanogenesis in pigmented skin equivalents and monolayer culture of melanocytes. J Dermatol Sci. 2001;27:68-75.

\section{Ready to submit your research? Choose BMC and benefit from:}

- fast, convenient online submission

- thorough peer review by experienced researchers in your field

- rapid publication on acceptance

- support for research data, including large and complex data types

- gold Open Access which fosters wider collaboration and increased citations

- maximum visibility for your research: over $100 \mathrm{M}$ website views per year

At BMC, research is always in progress.

Learn more biomedcentral.com/submissions 